\title{
METODE VAKT DAN MEDIA PASIR DAPAT MENINGKATKAN KEMAMPUAN MENULIS PERMULAAN BAGI ANAK TUNA GRAHITA SEDANG DI KELAS I SDLB-C YPAC MEDAN
}

\author{
Dasmiati \\ Surel:Dasmiati48@yahoo.co.id
}

\begin{abstract}
The purpose of this study is to prove that using the VACT Method and Sand media can improve students' abilities in writing the beginning. The research used is Classroom Action Research. The research subjects were 11 students consisting of 5 men and 2 women. The research model was developed by Suharsimi Arikunto. Because in a cycle or round consists of four components, namely: Planning (Planning), Actions (Acting), Observation (Observing), and Reflection (Reflecting). The results of the observation were only two students or (20\%) who were able to write the beginning. In the first cycle using the VAKT method and medically the ability increased to 4 students (40\%). In cycle II the researcher repeats the beginning of writing the same as the first cycle using the VAKT method and the Sand media, the students 'ability in writing the beginning increases to 7 students (70\%) Thus it can be concluded by using the VAKT method and sand media can improve students' ability in write the beginning of B. Indonesia's learning in Medan's ISDLBC YPAC class.
\end{abstract}

Keywords: VAKT Method, Mediapasir, Write The Beginning.

\begin{abstract}
ABSTRAK
Tujuan penelitian ini untuk membuktikan bahwa dengan memakai Metode VAKT dan media Pasir dapat meningkatkan kemampuan siswa dalam menulis permulaan. Penelitian yang digunakan adalah Classroom Action Research. Subjek penelitian adalah 11 orang siswa yang terdiri dari 5 lakilaki dan 2 perempuan.Model penelitian yang dikembangkan oleh Suharsimi Arikunto. Karena di dalam suatu siklus atau putaran terdiri dari empat komponen yaitu: perencanaan (Planning), Tindakan (Acting), Observasi (Observing), dan Refleksi (Reflecting). Hasil observasi hanya dua orang siswa atau $(20 \%)$ yang mampu menulis permulaan. Pada siklus I dengan menggunakan metode VAKT dan mediapasir kemampuannya meningkat menjadi 4 orang siswa (40\%). Pada siklus II peneliti mengulang kembali menulis permulaan sama dengan siklus I dengan memakai metode VAKT dan media Pasir, kemampuan siswa dalam menulis permulaan meningkat menjadi 7 orang siswa (70\%) Dengan demikian dapat disimpulkan dengan memakai metode VAKT dan media pasir dapat meningkatkan kemampuan siswa dalam menulis permulaan pada pembelajaran B. Indonesia di kelas 1 SDLBC YPAC Medan.
\end{abstract}

Kata kunci: Metode VAKT, Mediapasir, Menulis Permulaan.

\section{PENDAHULUAN}

Suatu komunikasi dikatakan berhasil apabila pesan yang disampaikan dapat dipahami dengan baik oleh penyimak atau pendengar. Menurut Tarigan dalam Irwansayah (1985: 2), keterampilan berbahasa (language arts atau language skills) 
dalam kurikulum mencakup empat jenis, yaitu keterampilan menyimak (listening skills), keterampilan berbicara (speaking skills), keterampilan membaca (reading skills) dan keterampilan menulis (writing skills). Mereka dapat belajar di sekolah untuk tujuan fungsional, mencapai satu tingkat dan tanggung jawab sosial dan mencapai penyesuaian sebagai pekerjaan dengan bantuan mereka mampu memperoleh keterampilan mengurus diri sendiri dan dapat mengadakan adaptasi sosial di rumah dan lingkungan dan belajar keterampilan dasar akademik berbahasa yang sesuai dengan kemampuannya, intelegensi anak tunagrahita sedang berkisar 30-50.

Di Sekolah Luar Biasa (SLB) YPAC Medan tempat penulis bekerja tepatnya di kelas D1 CI terdapat 11 orang siswa tuna grahita sedang. Hasil observasi yang penulis lakukan penulis menemukan hampir semua siswa belum bisa memegang pensil untuk menulis, sedangkan pada KTSP seorang guru sudah seharusnya mengajarkan menulis dan membaca permulaan (MMP) pada semester II di kelas I walau pun ini siswa tunagrahita sedang seorang guru juga harus berusaha memotivasi siswa agar mampu menulis permulaan walaupun hanya sesederhana mungkin dan semampu anak sesuai dengan kemampuan masing-masing.

MMP merupakan kependekan dari Membaca Menulis Permulaan. Sesuai dengan kepanjangannya itu,
MMP merupakan program pembelajaran yang diprioritaskan kepada kemampuan membaca dan menulis permulaan di kelas-kelas awal pada saat anak-anak mulai memasuki bangku sekolah. Pada tahap awal siswa tunagrahita sedang pada semester II ini menulis permulaan di kelas 1-CI Sekolah Luar Biasa (SLB), MMP merupakan menu utama. Mengapa disebut permulaan, dan apa sasarannya? Peralihan dari masa bermain di TK (bagi anak-anak yang mengalaminya) atau dari lingkungan rumah (bagi anak yang tidak menjalani masa di TK) ke dunia sekolah merupakan hal baru bagi anak.Hal pertama yang diajarkan kepada anak pada awal-awal masa persekolahan itu adalah kemampuan membaca dan menulis.

Kedua kemampuan ini akan menjadi landasan dasar bagi pemerolehan bidang-bidang ilmu lainnya di sekolah.Berangkat dari permasalahan yang peneliti temukan dilapangan, maka peneliti berkeinginan untuk meneliti permasalahan menulis permulaan pada anak tungrahita sedang. Untuk mewujudkan agar anak mampu menulis dengan baik bagi anak tunagrahita sedang bukan semudah mengajarkan pada anak normal atau anak tuna grahitaringan, seorang guru harus memiliki keterampilan mengajar yang benar dan mampu membawa anak ke arah pembelajaran yang menarik dan menyenangkan dari itu seorang guru anak tunagrahita sedang harus bisa 
memilh strategi, metode, pendekatan, teknik dan media yang tepat untuk digunakan dalam pembelajaran menulis permulaan bagi anak tunagrahita sedang.

Berdasarkan penemuan diatas penulis tertarik untuk mencoba salah satu metode. Dalam hal ini, peneliti ingin mencoba menggunakan Metode/tehnik VAKT dan media pasir untuk meningkatkan kemampuan menulis permulaan bagi anak tunagrahita sedang. Dengan Metode/tehnik VAKT, pembelajaran menulis pada siswa bisa lebih divariasikan melalui berbagai macam indra yang ada pada siswa sehingga pemahaman terhadap materi yang di berikan guru ke siswa dapat membuat siswa lebih paham dan mengingatkan kegiatan yang dapat menunjang kemampuan menulisnya. Disamping menggunakan metode VAKT peneliti juga menggunakan media pasir sebagai alat bantu untuk melatih motorik tangannya.

suatu $\begin{array}{cc}\text { Metode VAKT } & \text { merupakan } \\ \text { metode } & \text { pengajaran }\end{array}$ multisensoris yang dikembangkan oleh seorang ahli bernama Grace M. Fernald (Abdurrahman, 2003: 217). Oleh sebab itu, metode VAKT juga dikenal sebagai metode Fernald.Selain itu, ada juga yang mengenalnya sebagai pendekatan multisensoris karena pengajarannya melibatkan banyak sensori. Sesuai dengan pendapat Munawir (2005: 168), pendekatan multisensory didasarkan pada asumsi bahwa anak akan dapat belajar dengan baik jika materi pengajaran disajikan dalam berbagai modalitas yaitu visual (penglihatan), auditory (pendengaran), kinesthetic (gerakan), dan tactile (perabaan). Berdasarkan temuan di lapangan yang terjadi pada siswa tunagrahita sedang di kelas 1 SDLB-C YPAC Medan yang menjadi permasalahan belum mampu untuk memegang pensil serta menulis permulaan, kesulitan dalam menuliskan simbol huruf, hasil tulisan yang diperoleh terutama huruf vokal (a, i, u, e, o) belum terbaca dengan jelas, tulisannya belum menyerupai bentuk huruf yang sebenarnya. Agar penelitian ini terarah dan efektif maka peneliti membatasi masalah ini dengan judul penelitian meningkatkan kemampuan menulis permulaan dengan menggunakan metode VAKT dan media pasir bagi anak tunagrahita sedang kelas D I-C1 SDLB-CYPAC Medan.

Berdasarkan permasalahan yang telah di paparkan dalam latar belakang di atas, maka dapat dirumuskan permasalahan ini yaitu: “Apakah melalui metode VAKT dan media pasir dapat meningkatkan kemampuan menulis permulaan bagi anak tunagrahita sedang kelas DI-C1 di SDLB-C YPAC Medan? Berkaitan dengan permasalahan di atas, maka penelitian ini bertujuan untuk membuktikan melalui metode VAKT dan media pasir, dapat membantu meningkatkan kemampuan menulis permulaan bagi anak tunagrahita sedang kelas $\mathrm{C} 1$ SDLB-C YPAC Medan. 
Dasmiati: Metode VACT Dan Media Pasir Dapat...

$\begin{array}{ccc} & \text { Metode VAKT } & \text { merupakan } \\ \text { suatu } & \text { metode } & \text { pengajaran }\end{array}$ multisensoris yang dikembangkan oleh seorang ahli bernama Grace $\mathrm{M}$. Fernald (Abdurrahman, 2003: 217).Oleh sebab itu, metode VAKT juga dikenal sebagai metode Fernald.Selain itu, ada juga yang mengenalnya sebagai pendekatan multisensoris karena pengajarannya melibatkan banyak sensori. Sesuai dengan pendapat Munawir (2005: 168), pendekatan multisensory didasarkan pada asumsi bahwa anak akan dapat belajar dengan baik jika materi pengajaran disajikan dalam berbagai modalitas yaitu visual (penglihatan), auditory (pendengaran), kinesthetic (gerakan), dan tactile (perabaan). Sedangkan Edja Sadjaah (1995: 155) menyatakan bahwa metode VAKT merupakan metode dengan pendekatan multisensori karena dalam pelaksanaannya menggunakan banyak sensori seperti penglihatan, pendengaran, rasa dan raba serta indra lainnya sehingga anak dapat menghayatinya dengan penuh keyakinan.

Metode VAKT dapat kita kembangkan kegiatan pembelajaran menulisnya, dengan begitu siswa akan lebih termotivasi untuk belajar menulis.

Metode VAKT ini disebut juga dengan metode multi sensoris.Multisensori terdiri dari dua kata yaitu multi dan sensori. Menurut Kamus Besar Bahasa Indonesia (1999, h. 671), kata“multi" artinya banyak atau lebih dari satu atau dua, sedangkan "sensori" (KBBI, 1999, h916) artinya panca indera. Maka gabungan kedua kata ini berarti lebih dari satu panca indera. Yusuf (2003, h. 95) menyatakan, pendekatan multisensori mendasarkan pada asumsi bahwa anak akan dapat belajar dengan baik apabila materi pengajaran disajikan dalam berbagai modalitas alat indera. Modalitas yang dipakai adalah visual, auditoris, kinestetik, dan taktil, atau disingkat dengan VAKT.

Pendekatan membaca multisensori meliputi kegiatan menelusuri (perabaan), mendengarkan (auditoris), menulis (gerakan), dan melihat (visual). Untuk itu, pelaksanaan metode ini membutuhkan alat bantu (media) seperti kartu huruf, cat, pasir, huruf timbul, dan alat bantu lain yang sifatnya dapat diraba (konkret). Menurut pendapat peneliti VAKT lebih tepat dikatakan sebagai sebuah teknik pembelajaran bukan sebuah metode. Hal ini dikarenakan pelaksanaan VAKT didalam sebuah pembelajaran lebih kepada sebuah cara yang dilakukan dan diterapkan oleh guru untuk mendukung keberhasilan dari pelaksanaan metode pembelajaran lainnya seperti metode ceramah, latihan dan penugasan.

Bermain pasir sangat menyenangkan bagi anak.Tetap berikan pendampingan untuk memastikan keamanannya dan kebersihannya setiap setelah bermain pasir bawalah anak untuk mencuci tangannya. Dan jangan biarkan anak 
untuk bermain lebih lama tampa ada pengawasan karna nati bisa akan berakibat mencederai alat indra anak. Untuk itu pastikan keadaan pasir steril dari kuman dan lakukan pengawasan yang teliti agar tujuan yang di harapakan dapat tercapai dan kita dapat memanfaatkan pasir membantu meningkatkan kecerdasan anak.

\section{METODE PENELITIAN}

Penulisan yang dilakukan penulis adalah merupakan penulisan tindakan kelas (Class Room Action Research). Penelitian ini dilakukan di kelas 1 SDLB-C YPAC Medan Jln. Adinegoro no 2 Medan. Subjek penelitian adalah anak sekolah luar biasa SDLB-C YPAC Medan kelas I -C1 SDLB YPAC Medan semester II berjumlah 11 orang. Model PTK yang digunakan, kolaborasi, maksudnya; guru berkolaborasi dengan Kepala Sekolah dan guru SDLB-C YPAC Medan. Tempat penelitian dilakukan di SLB YPAC Medan Jln. Adinegoro No 2 Medan.

Sumber data dari penelitian ini berasal dari siswa kelas I-C1 SDLB-C YPAC Medan, kepala sekolah, guru kelas yang relevan, guru olah raga dan guru yang mengajar di SDLB-C YPAC Medan. Teknik pengumpulan data dalam jenis penelitian ini menggunakan teknik Observasi, dan wawancara.

Analisis data yang digunakan dalam penelitian ini adalah Analisis kualitatif, menurut Meleong berpendapat bahwa, dalam melakukan penelitian kuantitatif dan penelitian kualitataif secara bersamasama, dengan ketentuan dilakukan dengan bertahap-tahap (dalam iskandar. 2008. hal 25) antara lain: Tahap pertama, peneliti dapat menggunakan penelitian kualitatif dan pada tahap ke dua mengunakan penelitian kuantitatif, oleh sebab itu pendekatan kuantitatif dan pendekatan kualitatif dapat dilakukan secara bersama-sama dalam sebuah penelitian, dengan cara kerjanya di lakukan secara bertahap-tahap dan disainsnya adalah memberikan manfaat pada salah satu paradigma penelitian, sedangkan paradigma lainnya hanya sebagai pelengkap atau pendukung saja.

Penelitian tindakan kelas ini menggunakan analisis rata-rata skor dan persentase. Data tes dianalisis dengan menggunakan nilai rata-rata individu anak, dan kriteria ketuntasan belajar anak.

a. Nilai rata-rata

Nilai akhir rata-rata anak dihitung dengan menggunakan rumus :

$$
\bar{x}=\frac{\sum X}{N}
$$

Keterangan :

$\bar{x}=$ Nilai Akhir Rata-rata anak

$\Sigma \mathrm{X}=$ Jumlah Nilai akhir anak

$\mathrm{N}=$ Jumlah anak

(Suharsimi, 2002 :264) 
Persentase ketuntasan belajar secara klasikal atau perorangan Ketuntasan belajar secara klasikal dihitung dengan menggunakan rumus :

(Suharsimi, 1987)

$$
P=\frac{n}{N} x 100 \%
$$

Keterangan :

$\mathrm{P}=$ Tingkat Kemampuan

$\mathrm{n}=$ Jumlah nilai anak yang diperoleh dari data

$\mathrm{N}=$ Jumlah anak

$100 \%=$ Nilai Konstan

Penelitian tindakan kelas yang dilakukan oleh peneliti dimulai dengan adanya masalah yang dirasakan oleh peneliti saat melaksanakan pembelajaran dikelas. Masalah tersebut adalah masih kurangnya motivasi siswa dalam menulis permulaan terutma menulis huruf a,i,u,e,o. Setelah peneliti menemukan masalah dilanjudkan dengan menganalisa dan merumuskan, kemudian peneliti merencanakan Penulisan Tindakan Kelas (PTK) dalam bentuk perencanaan, tindakan, perbaikan, observasi dan melakukan refleksi.

Dengan demikian berdasarkan hasil tindakan atau pengalaman pada siklus I peneliti akan kembali mengikuti langkah perencanaan, pelaksanaan, pengamatan dan refleksi pada siklus ke II ini.

Indikator kinerja dalam penulisan tindakan kelas ini adalah: karakteristik yang ditunjukkan oleh suatu hasil dari tindakan yang dapat memperbandingkan tingkah laku dari objek yang di teliti. Adapun yang menjadi indikator kinerja sebagai keberhasilan dalam penelitian tindakan kelas ini adalah terjadinya peningkatan kemampuan menulis permulaan pada siswa 1-C1 SLB-C YAC Medan. Dimana selama ini anak sulit untuk memeagang pensil dan menulis vokal a i,u,e,o baik menebalkan tulisan maupun menyambung titik-titik yang sudah dibuat guru dan meningkatnya motivasi belajar siswa dalam kelas. Pada siklus I belum nampak perubahan yang ditunjukkan dalam kemampuan siswa namun sudah mengalami perubahan dibandingkan dengan pra observasi. Dengan menggunakan melatih siswa secara berulang-ulang sedikit demi sedikit dan kotinuinitas dapat meningkatkan kemampuan menulis permulaan bagi siswa tunagrahita sedang ke arah yang diharapkan.

\section{HASIL PENELITIAN DAN PEMBAHASAN}

Pada tahap perencanaan ini meliputi identifikasi, perumusan masalah dan analisis masalah. Berdasarkan dari hasil pengamatan dan pengalaman peneliti selama mengajar siswa tunagrahita yang belum mampu menulis permulaan terutama untuk memegang pensil dengan benar dan menebalkan huruf vokal a,i,u,e,o hanya 2 orang siswa saja yang bisa memegang pensil dengan benar dan menuliskan 
(menebalakan) huruf vokal dengan baik dan tenang waktu pembelajaran di kelas. Pada umumnya siswa tunagrahita sedang memang tergantung moodnya jika tidak lagi mood untuk belajar anak susah untuk konsentrasi untuk menerima pembelajran yang diberikan dengan demikian seorang guru harus mencobakan beberapa metode yang dapat meningkat motivasi belajar siswa dan begitu juga dengan media yang cocok dengan siswa.Peneliti dan kolaborator menyusun prosedur jadwal dan skenario tindakan jumlah pertemuan disesuaikan dengan program yang sudah ditentukan dengan tema kompetensi dasar menulis permulaan dan materi menulis huruf vokal a,i,u,e,o. Kegiatan yang dilakukan adalah menyusun strategi pelaksanaan tindakan yang dimulai dengan menyusun rencana pembelajaran membuat program tahunan, program semester, silabus dan rencana pelaksanaan pembelajaran yang berkompetensi dasar menulis permulaan dengan materi menulis vokal a,i,u,e,o.

Pada pelaksanaan tindakan ini kegiatan yang dilakukan peneliti adalah (1) Menyiapkan media yang diperlukan untuk pelaksanaan mulai dari kegiatan awal sampai kegiatan akhir, dapat dilihat dalam RPP secara terpisah yaitu menulis permulaan dan titik beratnya memegang pensil dengan benar, menimpa tulisan atau menebalkan tulisan menyambung titik yag ada pada tulisan. (2) Menyiapkan kelas meliputi, pengaturan tempat duduk siswa, dimana siswa di suruh duduk secara berbentuk lingkaran menghadap ke meja.

Berdasarkan perbaikan yang dilakukan guru untuk meningkatkan kemampuan menulis permulaan bagi anak tuna grahita sedang di kelas IC1 SLB-C YPAC Medan adalah sebagai berikut:

a. Terutama pengelolaan kelas penting untuk pelaksanaan pembelajaran, disamping itu guru juga harus bisa mengelola siswa agar siswa bisa mengikuti pembelajaran semestinya bisa menerima pembelajaran sewaktu proses belajar mengajar berlangsung di dalam kelas sesuai dengan indikator yang kita harapkan. Dalam pembelajaran kita mengharapkan anak merasa senang dalam belajar dan tidak merasa terpaksa untuk belajar karna kita ketahui anak ini disamping IQ dibawah normal juga hiperaktif. Namun dalam kegiatan ini belum semua anak yang mau aktif dan tenang dalam menerima pembelajaran yang diberikan guru.

b. Saat pembelajaran dikelas anakanak masih kurang termotivasi untuk belajar dengan baik, masih banyaknya anak yang tidak mau belajar menulis dan masih menggangu teman dan asyik bermain sendiri, dalam belajar belum begitu terdapat kemajuan. 
Hasil penilaian dari siklus 1 terlihat pada setiap guru memberikan pembelajaran di kelas siswa sudah mau dilatih untuk menulis dan menirukan gerakan-gerakan menulis yang diberikan guru dan sudah ada sudah bisa menebalkan huruf vokal a,i,u,e,o dimana pada tahap observasi hanya 2 orang saja yang dapat menebalkan vokal a,i,u,e,o yaitu Carlo dan Nisa yang dapat menebalkan tulisan yang diberikan guru dan setelah siklus 1 dilakukan sudah 4 orang yang mampu menebalkan vokal a,i,u,e,o yaitu Nisa, Carlo, Faiza, dan Salim yang bisa menebalkan huruf a,i,u e,o dan duduk tenang walaupun tidak lama, 4 orang siswa baru mampu memegang pensil dengan baik, 1 orang hanya bisa menulis di atas awan dan 2 orang sudah mampu menyambung titik-titik.Hal ini memang sudah mengalami peningkatan tapi belum seperti yang diharapkan.

Observasi dilakukan selama PTK dilaksanakan. Data observasi direkam dengan menggunakn daftar cek dan catatan terbuka serta dibantu dengan kamera. Perilaku anak yang selama ini dalam menerima pembelajran kurang termotivasi dan konsentrasi, selalu berpindah-pindah tempat walaupun pembelajran sedang berlangsung, karna mereka tidak berminat untuk belajar dan membosankan.

Disamping memberikan
penilaian tentang kemampuan
menulis permulaan pada siswa
peneliti juga menjejaki tentang
tingkah laku siswa dalam belajar.

Berdasarkan pengamatan peneliti pada siklus 1. Pada umumnya belum nampak sekali perubahan yang ada pada anak karena disebabkan kurang variatifnya media yang digunakan dan juga kurang tepatnya metode diberikan ceramah dan pemberian tugas dengan media buku pensil saja dan siswa kurang tertarik karna sudah biasa mereka lihat dan lakukan setiap hari, dan juga kemampuan anak tidak sama masih bervariasi dalam cara menerima pembelajaran yang diberikan guru.

\section{Pembahasan}

Selama tindakan telah dilaksanakan pada siklus 1 , peneliti dan kolaborator mengetahui bahwa pada umumnya kemampuan siswa dalam menulis permulaan terutama menebalkan huruf a,i,u,e,o masih kurang dan belum seperti harapan yang diinginkan. Dan tingkah laku anak dalam menerima pembelajran dikelas selalu belum menunjukkan tingkah yang baik. Setelah diadakan refleksi terhadap tindakan yang diberikan tampak ada beberapa hal yang perlu diperbaiki dan ditingkatkan. Kelemahan-kelemahan yang ada seperti masih banyak siswa yang belum mampu untuk menulis dan menebalkan huruf a,i,u,e,o dan tidak bisa duduk dengan tenang dan bermain-main dengan teman sebelahnya sehingga mereka kurang motivasi untuk belajar. Berdasarkan hasil tersebut, diputuskan untuk memperbaiki tindakan yang telah dilaksanakan yakni lebih memfokuskan perbaikan-perbaikan 
kelemahan yang terdapat pada siklus 1. Untuk memperbaiki atau meningkatkan kemampuan siswa dalam menulis permulaan peneliti ke arah yang lebih baik dan meningkatkan motivasi belajarnya maka peneliti pada siklus ke II ini mencoba menambah metode VAKT dan media pasir dengan melibatkan indra penglihatan (visual) indra pendengaran audio dengan gerakan (kinestetik) dan indra perabaan (taktil) Kemudian peneliti juga mencoba membuat tempat duduk secara berkeliling mengelilingi meja dan tidak diberi ruang ditangahnya sehingga siswa tidak bebas untuk bergerak.

\section{SIMPULAN}

Simpulan Hasil observasi hanya dua orang siswa atau (20\%) yang mampu menulis permulaan. Pada siklus I dengan menggunakan metode VAKT dan mediapasir kemampuannya meningkat menjadi 4 orang siswa (40\%). Pada siklus II peneliti mengulang kembali menulis permulaan sama dengan siklus I dengan memakai metode VAKT dan media Pasir, kemampuan siswa dalam menulis permulaan meningkat menjadi 7 orang siswa $(70 \%)$ Dengan demikian dapat disimpulkan dengan memakai metode VAKT dan media pasir dapat meningkatkan kemampuan siswa dalam menulis permulaan pada pembelajaran B. Indonesia di kelas 1 SD LBC YPAC Medan.

\section{DAFTAR RUJUKAN}

Arikunto, Suharsimi. 2007. Prosedur Penelitian Pendekatan Praktik. Jakarta: Bumi Aksara

Efendi, Muhammad. 2006. Pengantar Psicopedagogik Anak Berkelainan. Bandung: PT. Bumi Sinar grafika offset

Iskandar. 2008. Metodelogi Penelitian Sosial (kuantitatif, kualitatif). Jakarta: Gaung Persada Prees

J., Maria Wantah. 2007. Pengembangan Kemandirian Anak Tungrahita Mampu Latih. Jakarta: Depdiknas

Mampuniarti. 2007. Pendekatan Pembelajaran bagi Anak Tunagrahita Hambatan Mental. Jogjakarta: Kanva Publisineer

Moeloeng. 2006. Metode Penelitian Kualitatif. Bandung: Remaja Kosda Karya.

Patton. 2002. Pedoman, Wawancara. Jakarta: Rajawali Prees

Purwandari. 2007. Tehnik Analisis Data Dalam Penelitia. Jakarta: Rajawali Press

Saeful, Abdul Rahman. 2003. Pendidikan Luar Biasa. Jakarta: Depdiknas

Sumantri, Sutjihati. 2006. Psicologi Anak Luar Biasa. Jakarta: PT. Rafika Aditama. 
Dasmiati: Metode VACT Dan Media Pasir Dapat... 